\title{
Need of Financial Sustainability in the Service Sector Msmes of India
}

\author{
Mrugakshi Rajhans, Sakshi Borde
}

\begin{abstract}
The United Nations is taking an active part in the promotion and implementation of a sustainable approach in our surrounding environment, with the help of its 17 sustainable development goals (S.D. Gs). This paper touches upon the $8^{\text {th }}$ and $9^{\text {th }}$ Goals which propose Decent work, Economic growth, Industry, Innovation and sustainable Infrastructure. Researchers propose that these goals are very crucial in the development of our economy. The industrial sector of the country is the backbone of its economy and in India the Micro, Small and Medium Enterprises (M.S.M. Es) are the soul of its exponential growth. Keeping in mind the Importance of the M.S.M. Es and their growing potential, the government has taken various initiatives in the form of schemes and policies, to promote and sustain these small businesses. Service sector contributes to more than $54.40 \%$ to Gross added value (G.V.A.) whereas the manufacturing sector contributes significantly less than the services sector. Despite of this fact researchers have found out that the Government is more inclined towards M.S.M.E's in manufacturing sector and have opened a greater number of schemes and opportunities for them than the M.S.M.E's in the service sector. Today, 54.6 billion total M.S.M. Es are registered in India, 33\% are of the service sector. Review and comparison of the statistics and contributions of the M.S.M. Es in both these sectors presents a clear picture regarding the extensive contribution of the service M.S.M. Es and hence has outlined the need of differentiation. The research presents a factual analysis, of the need of more action plans especially the ones aiming at making the service M.S.M. Es financially strong and sustainable. They have a great potential of expansion, growth and can help create many new employment opportunities. Therefore, this paper is an attempt to highlight their contributions and emphasize how making these thriving M.S.M. Es, stand on their own feet is the need of the hour. Researchers believe that government schemes and action plans are one of the best and efficient mediums to achieve the SDGs and contribute towards sustainable development.
\end{abstract}

KEY WORDS: M.S.M.Es, Service Sector, Financial Sustainability, SDGs.

\section{INTRODUCTION}

The United Nations has created and formulated the Sustainable Development Goals in order to meet the needs of today without compromising the future of the upcoming generations. They aim towards optimizing the resources today in order to create a more inclusive, innovative and long-lasting industrial framework. Today, in the era of Globalization and Industrialization, it has become essential for the industries to attain a "higher level of economic productivity" and "increase their resource efficiency."

Revised Manuscript Received on February 06, 2020.

Corresponding Author

Dr. Mrugakshi Rajhansa, Faculty -BBA, Brihan Maharashtra College of Commerce College, Pune, Maharashtra, India.

E-mail:mrugakshi71@gmail.com

Sakshi Borade, BBA, Brihan Maharashtra College of Commerce College, Pune, Maharashtra, India.
It has become crucial for governments to invest their finances and resources in order to provide a push to the industries in their respective countries. The researchers believe that, especially, in a fast-developing country like India, it is critical for the government to invest in its small-scale industries or the (M.S.M. Es); which are the support system of its rapid economic growth and positive growth indexes.

In harmony with the rules of Micro, Small \& Medium Enterprises Development (M.S.M.E.D.) Act, 2006 the (M.S.M. Es) are defined and classified in two Classes:

1. Manufacturing Enterprises- The enterprises involved in the manufacture or production of goods pertaining to any industry specified in the first schedule to the industries (Development and regulation) Act, 1951) or employing plant and machinery in the process of value addition to the final product having a different name or character or use. The Manufacturing Enterprise are defined in terms of investment in Plant \& Machinery.

2. Service Enterprises: -The enterprises engaged in providing or rendering of services and are defined in terms of investment in equipment. The limit for investment in plant and machinery / equipment for manufacturing / service enterprises, as notified are as under:

Definition of M.S.M. Es

\begin{tabular}{|l|l|}
\hline \multicolumn{2}{|c|}{ Manufacturing Sector } \\
\hline Basis of the Definition & Investment in plant \& machinery \\
\hline Micro Enterprises & $\begin{array}{l}\text { Does not exceed twenty-five lakh } \\
\text { rupees }\end{array}$ \\
\hline Small Enterprises & $\begin{array}{l}\text { More than twenty-five lakh rupees } \\
\text { but does not exceed five crore } \\
\text { rupees }\end{array}$ \\
\hline Medium Enterprises & $\begin{array}{l}\text { More than five crore rupees but } \\
\text { does not exceed ten crore rupees }\end{array}$ \\
\hline Micro Enterprises & $\begin{array}{l}\text { More than ten lakh rupees but does } \\
\text { not exceed two crore rupees }\end{array}$ \\
\hline Basis of the Definition & \begin{tabular}{l} 
Investment in equipment \\
\hline
\end{tabular} \\
\hline
\end{tabular}




\begin{tabular}{|l|l|}
\hline Medium Enterprises & $\begin{array}{l}\text { More than two crore rupees but } \\
\text { does not exceed five crore rupees }\end{array}$ \\
\hline Source & $\underline{\text { https://msme.gov.in/know-about- }}$ \\
\hline
\end{tabular}

Table:I

\begin{tabular}{|c|r|r|r|c|}
\hline \multicolumn{5}{|c|}{ Number of MSMEs category wise } \\
\hline \multirow{2}{*}{ Activity Calegory } & \multicolumn{2}{|c|}{ Estimated Number of Enterpises (in lakh) } & \multirow{2}{*}{ Share (\%) } \\
\cline { 2 - 4 } & \multicolumn{1}{|c|}{ Rural } & \multicolumn{1}{|c|}{ Urban } & \multicolumn{1}{|c|}{ Total } & \\
Manufacturing & 114.14 & 82.50 & 196.65 & 31 \\
Trade & 108.71 & 121.64 & 230.35 & 36 \\
Other Services & 102.00 & 104.85 & 206.85 & 33 \\
Electrictity & 0.03 & 0.01 & 0.03 & 0 \\
All & 324.88 & 309.00 & 633.88 & 100 \\
\hline
\end{tabular}

Source: Annual Report of Ministity of MSME

"Non-captive electricty generetion and transmission and distribution by units not registered with the Central Electicity Authority

\section{Table: II}

"The services sector in India covers a wide array of activities extending from services provided by the most classy sectors like telecommunications, satellite mapping, and computer software to simple services like those done by the barber, the carpenter, and the plumber; highly capital-intensive activities like civil aviation and shipping to employment-oriented activities like tourism, real estate, and housing; infrastructurerelated activities like railways, roadways, and ports to social sector related activities like health and education. Thus, there is no such definition of services which results in the overlapping of some borderline attachments. The National Accounts classification of the services sector combines trade, hotels, and restaurants, transport, storage, and communication, financing, insurance, real estate, and business services; and community, social, and personal services. In the World Trade Organization (W.T.O.) list of services and the Reserve Bank of India (R.B.I.) classified list, construction is also included." The service M.S.M. Es in India provide almost all of these services throughout the country. Not only are they profitable but they also contribute socially by providing a large number of employment opportunities. They contribute to about $54.40 \%$ of India's total G.V.A. They have a contribution towards the economy individually and at the same time act as supporting and ancillary units for the Manufacturing M.S.M. Es and help them do their part. It is being observed by the researchers that even though the service M.S.M. Es are contributing immensely towards industrial growth and employment generation, they receive very little attention from the Central and their respective State Governments. Despite their contribution, a review of the current schemes of the government and comparison of the performance statistics of the M.S.M.E's, points towards the disparity of the schemes and action plans towards the service M.S.M.E's and hence has outlined the need for differentiation.
Therefore, the researchers believe that it is the need of the hour for the government to validate the importance and the contribution of the service M.S.M.E's towards the Indian economy and increase their access to better financial opportunities, technical assistance and incentives in order to integrate them into the bigger picture of India's Economy since it will provide better opportunities and help create a more sustainable model of our economy for the budding future Entrepreneurs.

- [1]Source:https://www.indiabudget.gov.in/budget20142015/survey.asp

\section{OBJECTIVES}

1. Highlight the implementation of the $8^{\text {th }}$ and $9^{\text {th }}$ sustainable development goals in the Indian Economy.

2. Present a factual analysis of the current performance statistics of the Indian service sector and the Indian M.S.M.Es.

3. Throw light over the contributions of the service sector M.S.M.Es in stabilizing the Indian Economy.

4. To study the Economic Survey and RBI reports in order to factually present the progress of the service sector in India.

5. To highlight the potential of the service sector in India.

6 . To highlight the need of financial sustainability of the service sector for the development of the sector.

7. In the light of the recommendations provided by RBI give suggestions regarding better schemes and action plans for the service sector MSME's in India.

\section{LITERATURE REVIEW}

1)The Organization for Economic Co-operation and Development (O.E.C.D.): O.E.C.D. Active with India: (2018/2019): (Development, 2018-2019) O.E.C.D. being and active international organization is working with India to bring structural reforms in its development policies and in order to bring India into the global framework of development. The progressive collaboration between the entities aims to achieve the 2030 agenda for Sustainable Development. According to ANGEL GURRÍA, SecretaryGeneral of O.E.C.D.; India has established itself as one of the fastest expanding G-20 economy with a projected growth rate of around $7.5 \%$ in 2019. According to him "India is poised to become the $5^{\text {th }}$ largest economy in 2018." Due to these favorable statistics O.E.C.D. wants to advance its collaboration to promote inclusive growth all over the country

2)Statistics Times: Sector-wise contribution of the Gross domestic product (G.D.P.) of India: $8^{\text {th }}$ Feb 2019 (World Economic Outlook Database 2019, 2019)

According to the article, India's service sector stands at the $8^{\text {th }}$ position in the world and has a G.D.P. of $\$ 1500$ billion. Service sector is the largest sector in India and has a contribution of about $61.5 \%$. its G.V.A. at current prices in 2018-2019 is estimated to be around 92.26 lakh crore INR. It contributes substantially more than the Agriculture and the Industrial sector. It has a lion's share of $54.40 \%$ of India's total G.V.A. of 169.61 lakh crore I.N.R. This indicates that the service

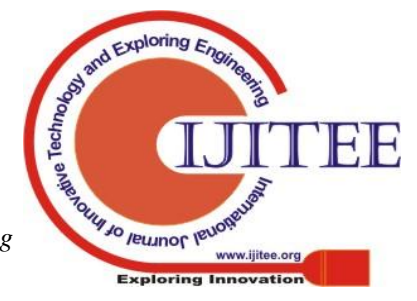


sector is contributing towards a very large share in the Indian economy in monetary terms.

3)International Chamber for Service Industry (I.C.O.S.I.): (ICSI, 2018)

According to the article, the M.S.M.Es in the Service Sector provide a large amount of employment opportunities. Close to almost $60 \%$ of the total opportunities provided by the entire M.S.M.E. sector in both the rural and urban areas. The service M.S.M.Es are growing at a faster rate as compared to the M.S.M.Es in the manufacturing sector of India. The article also expresses how the M.S.M.Es in the service sector are" The driving force for the growing engine of the Indian Economy." The government with its Standup and Startup India initiative, wants to nurture and motivate the entrepreneurs to become job creators which in turn will create a more sustainable ecosystem and provide more employment opportunities. The service M.S.M.Es are not only profitable but also support the manufacturing ones and help them flourish in turn leading to a balanced development.

4)India Brand Equity Foundation: (IBEF, 2018) The I.B.E.F. document highlights the advantages of a robust demand, competitive advantage and Increasing investments in the Indian service sector. It provides an overview of the various services that together compose the Indian service sector and graphically depict how its share is growing at the fastest CAGR of 6.93 per cent - US\$ 1,266.1 billion in FY18E in comparison with US\$ 846.8 billion in FY12. With the help of the Purchasing Managers' Index (P.M.I.), it is emphasizing how growth in the sector has been the fastest since June 2017. One of the main components and driver of India's growth is the exports from the service industry. "India ranked as the ninth largest exporter of commercial services in the world in 2017." The document presents an analysis of the major service sectors and their respective contributions as well as the challenges faced by them.

5)Deloitte and CII: Global Exhibition on services (The India Opportunity): April. 2017. (services, 2017) The collaborative report of Deloitte and CII reinstates the fact of how the M.S.M.Es have been the "Engines of India's development" for several decades and reestablishes their economic and social impact. It narrates the facts of the greater share of contribution, that the Indian service sector has towards the country's GDP and net exports.

Since many decades, the traditional Indian M.S.M.Es have faced the challenges of inadequate logistics and marketing, inadequate finances, lack of technical support and stringent government regulations which have hampered their success. Nevertheless, Indian M.S.M.Es have always survived and thrived in challenging business environments. The Information Technology services are expanding themselves and are also helping traditional businesses take the "big leap". They give necessary aids which are required for providing the customers with better products and services in an efficient manner. The report emphasizes that if the M.S.M.E's are given more of these IT services and are provided with better and easy access to risk capital, they will be able to tap and serve a much larger market and transform themselves into "Startups". This can inspire the youth of the country to become job creators, take India even further and establish it as a leader in this race.

6)Economic Times - Rise India: Most powerful engine of India's growth: Service M.S.M.Es (Mos18According to the article, the Indian service sector is the fastest growing sector among the three and has shown significant growth in the past few decades. The article also suggests how the service sector also has a positive influence over its surrounding economies and helps them flourish as well. It also highlights how, a developing nation like India must focus on the growth and development of its M.S.M.Es and contribute towards its success. It explains the range of these service M.S.M.Es, about how the vary from large IT firms to small astrologers, packers and movers, accountants, caterers, yoga instructors etc. It elaborates the challenges faced by these service M.S.M.Es, ranging from lack of work and supportive finances to problems related to affordability and excessive external control. It concludes with a short list of initiatives from both the central and state governments for these M.S.M.Es.

7)Sector in India: A Paradigm Shift - Invest India; National Investment promotion and facilitation agency (Nat19) The blog enlightens how the service sector in India is a very good example of exponential growth in a very short period. It supports the explanation with the facts related to its contribution to the G.V.A., the employment rate in the sector and the components of the sector which have a great potential for development. The blog emphasizes how, even after continuous growth in the sector it is not able to employ adequate number of individuals and still, maximum of the country's population sustains on the agriculture and manufacturing sector. This, according to the article can prove to be an economic problem soon and therefore points towards the need of an immediate, corrective action and "out of the box ideas" for utilizing the full potential of the service sector. To allow "equitable economic growth" to flourish in the country.

\section{ANALYSIS}

Indian Economy's Sectoral Breakup

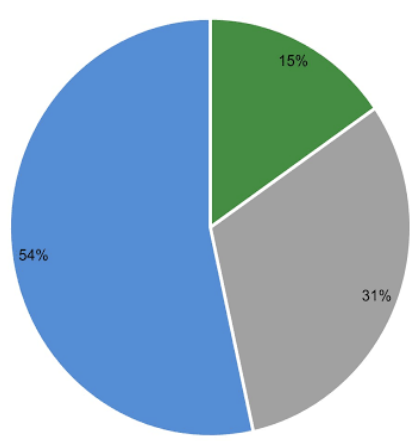

Market Realist $^{Q}$

- Agriculture, forestry \& fishing - Industry - Services Source: Central Statistics Office, India

Graph: I 
The Indian service sector is about 54\% of the total Indian economy. It is the major sector in the economy and is spread into diverse services.

\section{Sectoral G.V.A. Contribution}

\begin{tabular}{|l|c|c|c|c|}
\hline Sector & $\%$ GVA & $\begin{array}{c}\text { GVA } \\
\text { growth } \\
\text { rate }\end{array}$ & $\begin{array}{c}\text { Workforce } \\
\text { distribution }\end{array}$ & $\begin{array}{c}\text { Per- } \\
\text { capita } \\
\text { GVA } \\
\text { (INR) }\end{array}$ \\
\hline Agriculture & $17.3 \%$ & $3.4 \%$ & $42.7 \%$ & 41,621 \\
\hline Industry & $29.0 \%$ & $5.5 . \%$ & $23.8 \%$ & $1,25,231$ \\
\hline Services & $53.7 \%$ & $7.6 \%$ & $33.5 \%$ & $1,64,569$ \\
\hline
\end{tabular}

Source: Economic Survey of India 2018-19

\section{Table: III}

The service sector has maximum contribution towards the G.V.A. of the country and contributes significantly more than the agricultural and the Industrial sector. This contribution takes place even though the workforce employed in this sector is considerably less. It shows that with minimum resources, the service sector is able to generate maximum profits. It is not only making profits, but is also covering up for the deficit created by the other two sectors.

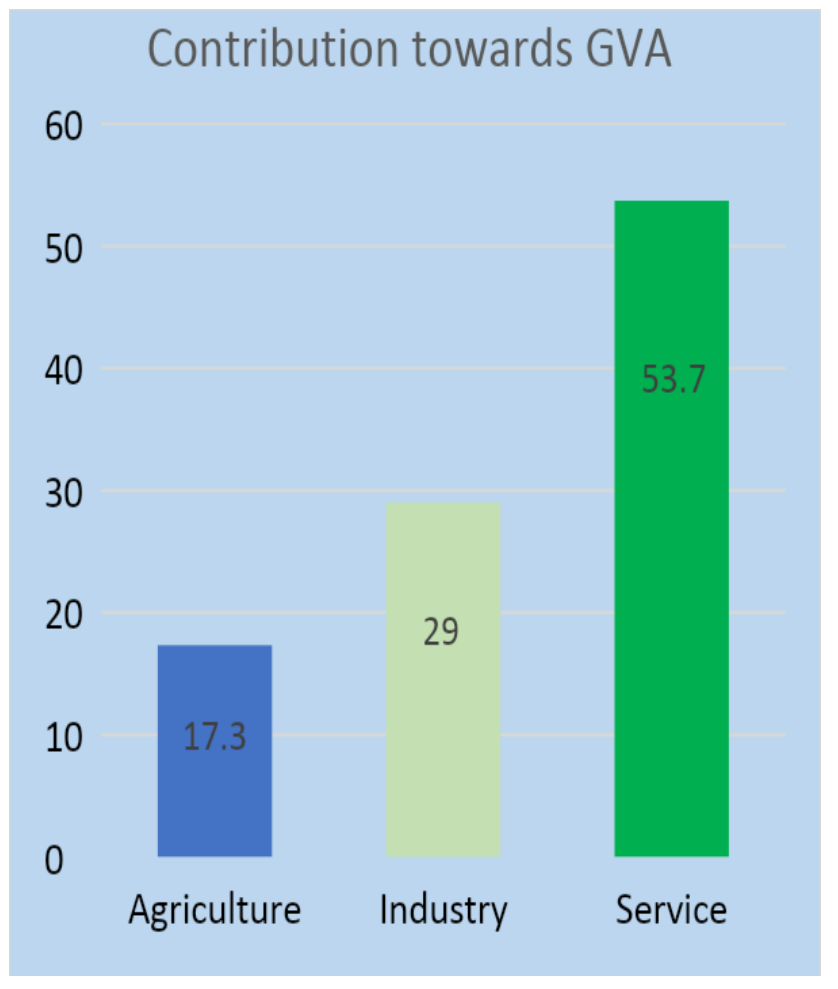

Source: Economic Survey of India 2018-19

Graph: II

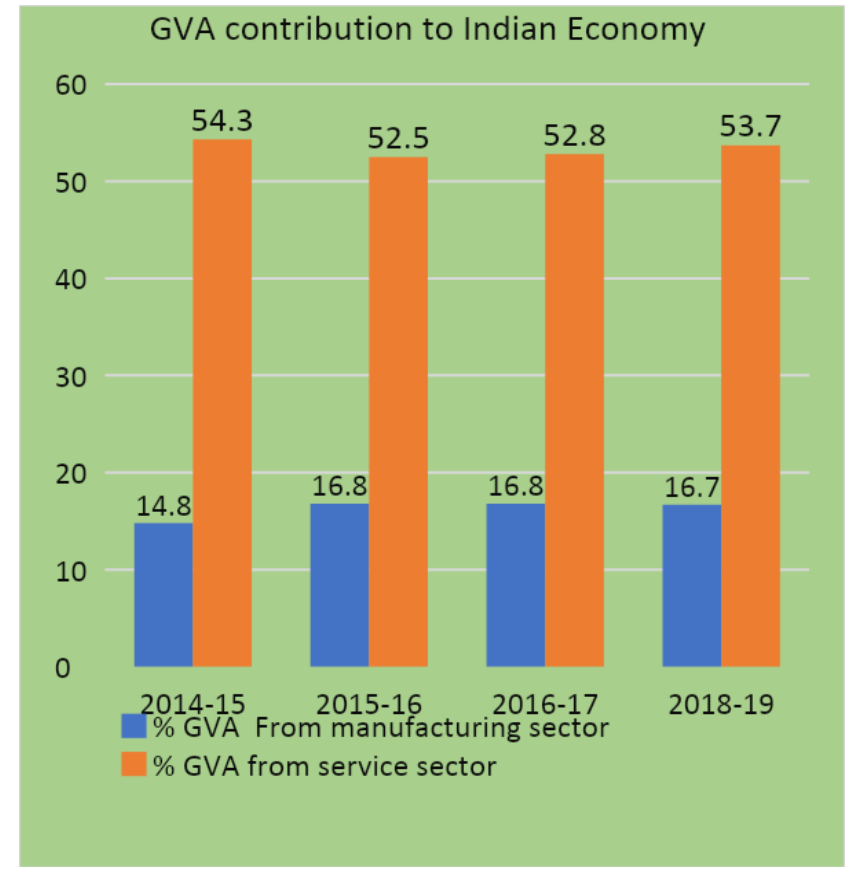

Source: Economic Survey of India 2018-19

\section{Graph: III}

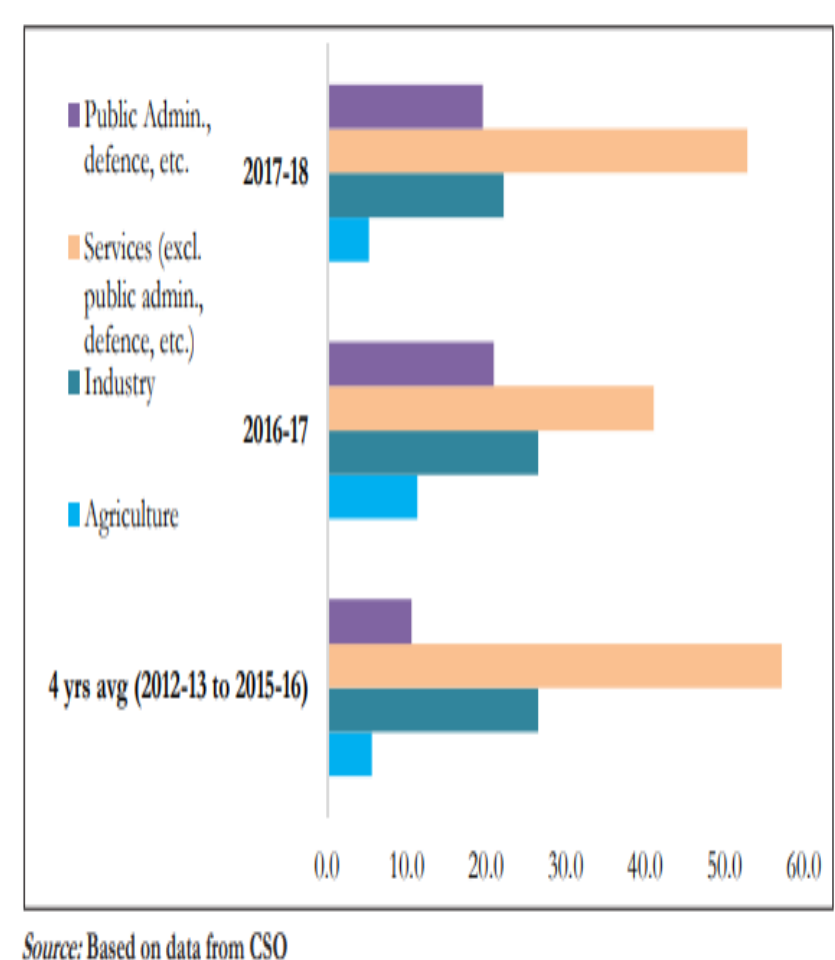

Source: Based on data from CSO

\section{Graph: IV}


Figure 6: ICT service exports (\% of service exports)

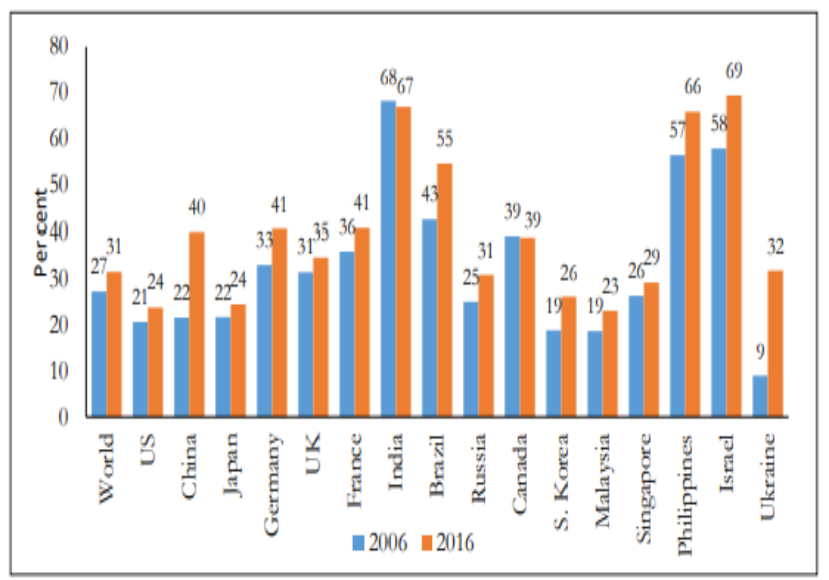

Source: Based on World Bank Database accessed on 19 January, 2018

Graph: V

India is among the top 10 countries with respect to its service exports. The main shareholder of these exports is the service M.S.M.Es in the country. IT is one of the main services exported by India worldwide.

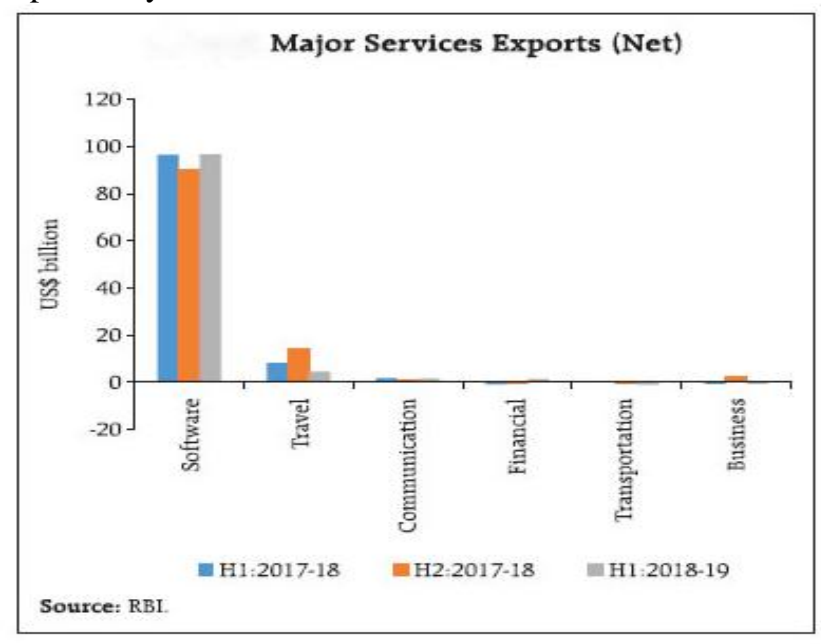

\section{Graph:VI}

\begin{tabular}{|c|c|c|c|c|c|c|}
\hline \multirow[b]{2}{*}{ Year } & \multicolumn{6}{|c|}{ Contribution of MSMEs in Country's Economy at Current Price (in Z C croore) } \\
\hline & MSME GVA & Growth (\%) & Total GVA & $\begin{array}{l}\text { Share of } \\
\text { MSWE in } \\
\text { GVA }(\%)\end{array}$ & Total GDP & $\begin{array}{l}\text { Share of } \\
\text { MSME in } \\
\text { GDP (\%) }\end{array}$ \\
\hline 2012:13 & 2977623 & 15.27 & 9202692 & 32.36 & 9944013 & 29.94 \\
\hline 2013-14 & 3343009 & 12.27 & 10363153 & 32.26 & 11233522 & 29.76 \\
\hline 201415 & 3658196 & 9.43 & 11481794 & 31.86 & 12455128 & 29.39 \\
\hline 2015.16 & 3936788 & 7.62 & 12458642 & 31.60 & 13682035 & 28.77 \\
\hline
\end{tabular}

Sourc: Annual Report Ministy of MSME 2017-18

Table: IV
The M.S.M.Es have a large and steady contributions towards India's economy and have considerable stake in the country's GDP.

\section{SME Service sector startups}

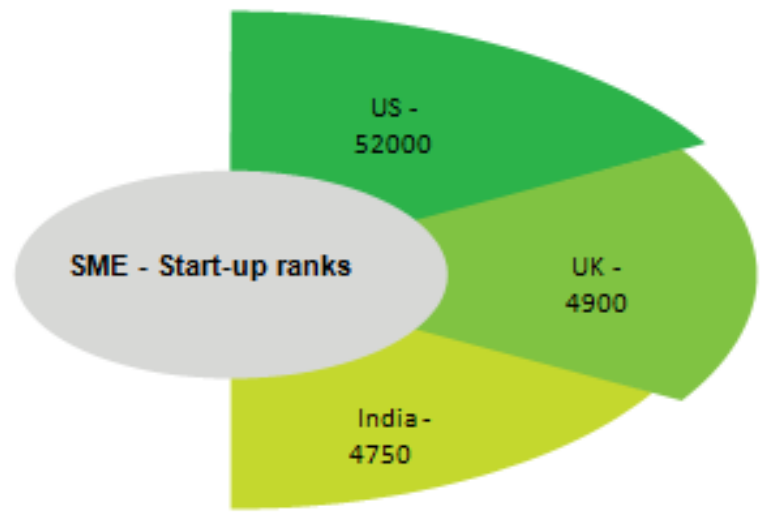

Graph: VII

Source: Confederation of Indian industry - Deloitte

\section{Top Tech Startup Countries}

According to the data from NASSCOM, India is one of the growing hubs of startups and is very close to competing with the UK. This indicates that the employment opportunities may rise in India soon and the youth is shifting from being job seekers to job givers. This also indicates a boost for the M.S.M.E. sector since with the increasing statistics, more and more of the Micro Medium and Small-scale Enterprises can be transformed into innovative and profitable startups.

\section{CONCLUSIONS AND SUGGESTIONS}

An analysis of the June 2019 report of RBI gives a clear picture of the challenges faced by the service sector M.S.M.Es. Regardless of their enormous and positive contribution to the economy, they still struggle in various ways. To begin with, one of the basic challenges that the service M.S.M.Es face is, the very basic definition of an MSME. According to the M.S.M.E.D. Act, 2006 the M.S.M.Es are defined on the basis of their investment in Plant \& Machinery and Equipment. This definition turnout to be highly unfair for the service sector M.S.M.E.'s, since they deal with less equipment thereby affecting their financial aids and incentives since they are not placed in the accurate category of enterprises. Recently, the government has been working on a new definition for the M.S.M.Es and has proposed to define the M.S.M.Es depending on the turnover of the enterprise. Another proposal is also considering a definition based on employability. In both these recommendations, there is a winwin situation for the Service M.S.M.Es since they have high turnovers with the help of less amount of workforce. With the more progressive upcoming definition, they will get placed in the right categories and receive their due incentives.

Marketing is one of the most essential business techniques needed for a business to flourish. In today's eras of

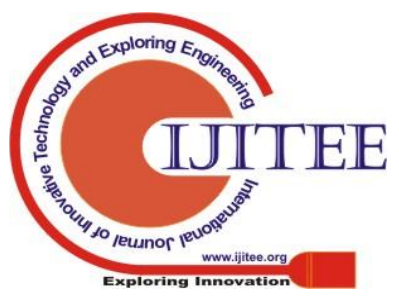


globalization, it is very imperative for businesses to have an international reach and they should be able to compete with other companies in the global market. Marketing helps in creating that creative and international image for an enterprise. Unfortunately, due to reasons like Lack of marketing expertise, Lack of online presence of M.S.M.E's and majorly, due to lack of awareness the service M.S.M.Es are not able to reach the global markets and take the advantage of a much bigger, dynamic and demand intensive market. the solutions of this problem but other ways could also include support and collaboration from the private enterprises either in the form of technical support or in the form of collaborations and partnerships like how Amazon did with the help of 'Kala Haat' which gave the local handicraft artisans in India, a global reach through their website.

Currently, another major problem for the service M.S.M.Es is that, the growth of the M.S.M.Es is unbalanced and nonuniform. The schemes and action plans of the government tend to favor the manufacturing sector more than the M.S.M.Es of the service sector. They do not get equal opportunities and incentives in order to flourish. The uneven distribution of growth and governmental support hampers the success and holistic development of the Service M.S.M.Es and the business eco system as a whole.

There is a need to fill these gaps with the help of corrective. accurate reforms and plans. Proper policy framing and implementation is also needed in order to promote the M.S.M.E. clusters in the new hubs.

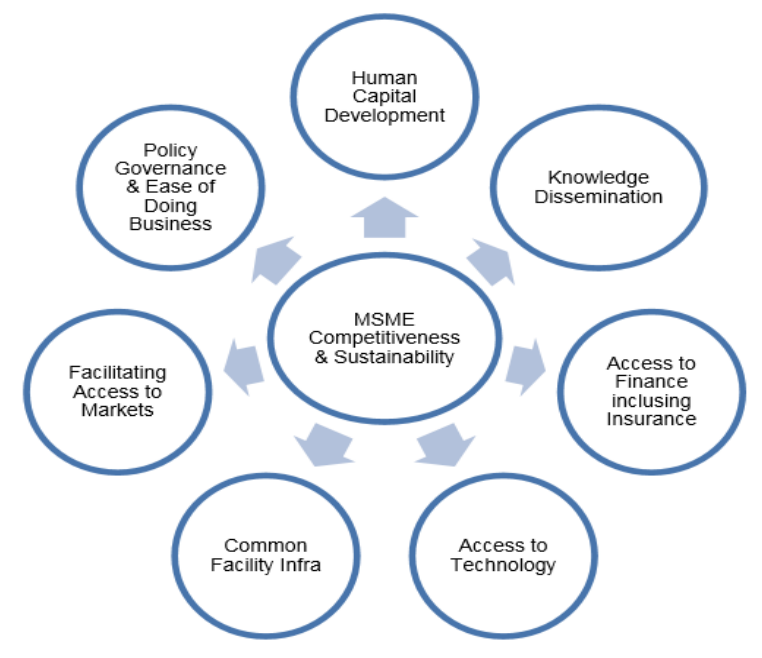

Source: R.B.I. report June 2019

\section{Graph: VIII}

The table above suggests that even after the realignment, there are gaps that remain to be still addressed. The intensity of these gaps varies across different regions of the country. The condition does not change much when a parallel mapping is done for schemes of other ministries.

In the aspect of financial challenges, one of the biggest one is that of Cash Crunch due to the delayed payments from the debtors. Big companies tend to treat these small enterprises like a bank and therefore do not pay them on time. This lag in payments affects their day to day functioning and leads to a
The Marketing assistance scheme of the government is one of

cash crunch due to unavailability of enough Working Capital. This delay in payments also leads to elongated Working Capital cycles, which can also go until 100 days. This could also lead to loss of future business for some of them.

Information utility can be used to solve this problem. With the help of these IUs, the small enterprises could file the name and the default amount of the debtor. This could be dealt with by either paying the interest for every day after the due date or by stringent actions taken by a senior authority.

\section{"M.S.M.E. Credit Demand and Gap Estimates in India:}

The total available demand for external credit is projected to be ₹37 trillion 6 while the total supply of finance from formal sources is valued to be ₹14.5 trillion Therefore, the complete credit gap in the M.S.M.E. sector is assessed to be ₹20 - 25 trillion."

The R.B.I. Expert opinion report of June 2019 has recommended a cash flow loan facility for the M.S.M.E.'s. according to this facility the loans are not based on the borrower or project assessment, but it is based on the receipt estimates of the future cash flow. This recommendation will help the service sector M.S.M.Es in filling their cash requirement gap.

This shows that there is a tremendous requirement of funding needed to fill this gap of credit availability and the sourcing needs to be done from more progressive and non-conventional sources.

Further research can be conducted on the implementation of the various schemes available for the M.S.M.E.'s. Research can also be conducted on the demands of the service sector M.S.M.E.'s for supporting them in doing business.

\section{REFERENCES:}

1. Lahiri, Rajib. (2019). PROBLEMS AND PROSPECTS OF MICRO, SMALL AND MEDIUM ENTERPRISES (M.S.M.ES) IN INDIA IN THE ERA OF GLOBALIZATION.

2. Mukherjee, Sonia. (2018). Challenges to Indian micro small scale and medium enterprises in the era of globalization. Journal of Global Entrepreneurship Research. 8. 10.1186/s40497-018-0115-5.

3. Bhasin, Niti. (2015). Determinants of Foreign Direct Investment in India's Service Sector. MUDRA: Journal of Finance and Accounting. 1. 10.17492/mudra. v1i1.2457.

4. Ghosh, Aniruddha. (2015). Financial gap analysis in MSME - A Study of Financial Position of MSME's In India. Vidya International Journal of Management Research.

5. Economic Survey report 2018-19 https://pib.gov.in/newsite/PrintRelease

6. Experts committee report on MSME 2019 https://www.rbi.org.in

7. Statistics times of India

8. http://statisticstimes.com/economy/sectorwise-gdp-contribution-ofindia.php

9. Sector wise contribution towards GDP https://www.jagranjosh.com/general-knowledge/what-is-the-sectorwisecontribution-in-gdp-of-india-1519797705-1

10. Economic survey 2017-18 report - service sector contribution in GVA

11. https://www.indiainfoline.com/article/news-union-budget-economicsurvey/economic-survey-2017-18-services-sector-contributed-almost72-5-of-gva-growth-in-2017-18-118012900155_1.html

12. Banga, Rashmi. (2005). Critical Issues in India's Service-Led Growth.

13. Department of Industrial Policy and promotion (2016) SKILL DEVELOPMENT SECTOR - THE ACHIEVEMENT REPORT

14. RBI (2019) REPORT ON EXPERT COMMITTEE OF MSME

15. ECONOMIC SURVEY REPORT (2018-19)

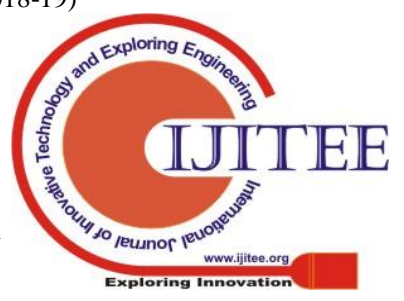


16. CII (2017) India Services Sector, A Multi-trillion Dollar Opportunity for Global Symbiotic Growth

17. IBEF (2018) SERVICES IN INDIA

\section{AUTHORS PROFILE}

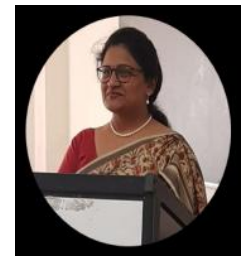

Dr. Mrugakshi Rajhans - M.com, M.B.A.(Fin), M.Phil. PGDIBO - Teaching Experience over 13 years.

Published articles - a) GST and its impact on Indian Economy - International research journal of Multidisciplinary studies. Vol IV Sp. Issue VIII Feb 2018 ISSN: $2454-8499$ b) Improving environment for business of the MSMEs - National conference Strat-ups, its scope, challenges and limitations. Vol 07 Feb 2018 ISBN No.: 978-81-923768-6. Won the first award as a research guide in MCCIA on HR live industrial projects. Authored 8 E-content's for UGC - India.

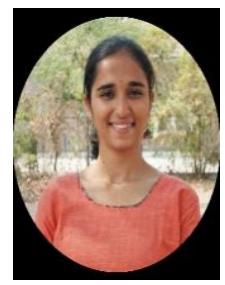

Ms. Sakshi Borde, Pursuing BBA (Finance) from Brihan Maharashtra College of Commerce, Pune.

Completed Diplôme d'Etudes en Langue Française (DELF) B2, the diploma awarded by the French Ministry of Education to prove French language efficiency and C1 Level in French from Alliance Française de Pune.

Publication: Presented a Research Paper entitled "Swamiji's thoughts on the Bhagvada Gita" in the National Conference on Sustainable Development"Swami Vivekanand' Contribution."

The paper was published in an International Multidisciplinary Quarterly Research Journal AJANTA. 